\title{
MULTICULTURALISM, CITIZENSHIP, AND EDUCATION IN MOROCCO
}

\author{
MOHA ENNAJI
}

\begin{abstract}
Morocco has a long history of multiculturalism and language contact; however, this characteristic has become more prominent as a consequence of the expansion of education after independence. This paper investigates how multiculturalism and citizenship in Moroccan society impact on the system of education. It provides a framework that enriches the discussion of multiculturalism and citizenship by highlighting the role that education plays in the development and management of multiculturalism and citizenship. The paper discusses the interlocked phenomena of multiculturalism, citizenship, and education from an interdisciplinary standpoint, analysing and explaining the synchronic relationships between them. The educational system must address the linguistic and cultural diversity inherent in multicultural Morocco, from the human rights and intercultural learning perspectives. Its purpose is not to teach the role of multiculturalism in official curricula, but to construct an approach to intercultural learning that promotes citizenship, dialogue, mutual understanding, and living together. Such an approach differs from the monocultural approach still existent in many North African and Middle Eastern curricula.
\end{abstract}

\section{Introduction}

$\boldsymbol{T}$ his paper discusses the close linkage between multiculturalism, citizenship, and education in Morocco. It deals with the changing role of education, the concept of citizenship inherent in it, and the relation of multiculturalism to wider society from the early years of French occupation in $20^{\text {th }}$ century Morocco to the present. These complex concepts are discussed through an analysis of the policies of education without losing sight of their impact on the concepts of knowledge and power in Morocco.

The language-culture interface is commonly acknowledged as an important symbol of citizenship and group identity, often engendering solidarity among communities and feelings of belonging to larger populations. In the Moroccan context, highly interesting issues arise in the construction of an adequate system of education and of national identity in the interaction of different languages, namely Arabic, Berber, French, Spanish, and recently English. 
The approach that I adopt is that of anthropological linguistics, based on the relationship between bilingualism, biculturalism, and education. This approach takes for granted the strong link between language, education, and culture as well as the idea of concurrence of multiple variables like class, gender, attitude, and the channel of communication. The paper is also inspired by studies on multiculturalism and society by Bourdieu (1982), Eickelman (1985), Fairclough (1989), and Kymlicka (1995), which are applied to investigate the relationship between multilingualism, multiculturalism, citizenship, and education in Morocco. In line with Kymlicka (1995), I argue that group-specific rights are consistent with citizenship and liberalism. Minority rights should be protected in order to promote equality. I propose that societies need to become more welcoming and inclusive than they are currently in respect of group rights. I am mostly supportive of the recognition and preservation of the distinctive patterns of 'minority' cultures. In this framework, a genuinely multicultural community would seek to promote the recognition of national ethnic difference through education and other means.

The construction of common cultures of difference at the national level remains one of the key objectives of multiculturalism. In cultures where citizenship is predominantly formulated through national institutions such as education and government, these perspectives remain important. Yet the debate thus far presupposes that multicultural concerns are questions exclusively for national contexts. Such formulations are inadequate in that modern societies have become marked by globalisation and migrations of people that defy the exclusive role of citizenship (Stevenson, 2002).

The paper also aims to demonstrate that multiculturalism in Morocco - and in the world at large - has reached a significant level in terms of scale and importance. While adopting Sklair's (1999, p. 154) idea that 'it is absolutely fundamental that we are clear about the extent to which the many different structures within which we live are the same in the most important respects as they have been or different', I would like to argue along the lines of Fishman (1998) and Maurais (2003), among others, that multiculturalism today is developing within the context of globalisation and is in fact 'qualitatively different' from what it was before, as it represents in effect a new cultural and social trend with increasingly deep effects on citizenship and education (Aronin \& Singleton, 2008).

The paper asks the following questions: First, how far are ideas of the national community inclusive or exclusive? To what extent does the state generate and how does it sustain definitions of citizenship? How important are factors like social movements, politics, and education in constructing a sense of identity?

This paper is divided into five sections. Section one deals with multiculturalism and citizenship in the global and national contexts. The second 
section focuses on the historical background of Morocco. Section three is concerned with the sociolinguistic context, more particularly aspects of multilingualism. Section four discusses the challenges of Arabisation and bilingual education. Finally, section five deals with the role of Berber education in the development and management of multiculturalism and citizenship.

\section{Multiculturalism and citizenship}

Before embarking on issues relevant to multiculturalism, citizenship, and education, it is useful to provide some definitions. I want to acknowledge immediately that terms such as 'multiculturalism' and 'citizenship' are ambiguous. In fact, there appears to be a clear relation between these concepts. For the purposes of the present paper, I define 'multiculturalism' in its inclusive sense, as the acquisition and use of a plurality of cultures. Multiculturalism acknowledges that cultures are characterised by a range of distinctive values and attitudes; it can disrupt processes of assimilation or globalisation by protecting the specificity of individual cultures from absorption into more dominant ones. The concept of multiculturalism can be descriptive and refer to an actual condition of a society, namely that a multiplicity of cultures is present and represents a significant proportion of the population. Or it can be normative and refer to a desired state of a society. As a normative concept, it can refer to an official government policy, as in the Canadian or Australian contexts, or it can refer to an idea that is instantiated to a greater or lesser extent in actual societies. The ideas can be stronger or weaker but in all cases would demand that cultural differences found in a society be accepted and respected by both societal institutions and members of the public alike.

As for the term 'citizenship', it refers to the rights and obligations that define an individual's membership of the political community. The study of citizenship needs to engage with both multicultural and educational questions. Bringing these issues together is possible if citizenship opens questions of cultural identity, and multiculturalism decouples itself from specifically national concerns. My argumentative strategy is that such questions are both central to any contemporary consideration of citizenship, and vital for future debates of educational issues and social and political theory.

In whichever way one seeks to define concepts of citizenship and national identity, 'imagined communities' attain an extraordinary impact as real social phenomena in which people believe and on which they act. The French sociologist Émile Durkheim's injunction to 'treat social facts as things' becomes brutally relevant when people are looked down upon because of (imagined) 'racial inferiority', or when diversity is disrespected ${ }^{1}$. 
Multiculturalism need not be considered exclusively as a device for integration. It could just as well be considered as an instrument for bringing about a form of preserving cultural, religious, racial, ethnic, linguistic, or other forms of diversity.

The discourses of human rights have created an alternative need and source for the legitimation of individual and collective rights other than membership of a nation. For example, the International Labour Organisation defines and monitors the observance of the rights of migrant workers, demanding and obtaining for them entitlements which at one time only citizens of a country might customarily have expected to receive. What we have is a trend toward a new model of membership anchored in de-territorialised notions of persons' rights. Classical conceptions of citizenship are no longer adequate in understanding the dynamics of membership and belonging to a country or a community.

Entitlement to citizenship carries with it a host of specific rights and responsibilities: rights to residence, education, and work, assorted benefits, political representation and participation and, often, associated obligations to the wider community.

Citizenship has wider, affective connotations too: the sense of belonging to a broader community, expressed in symbols and values, and the often quite vehement emotional identification which may be associated with that wider community of belonging. Conversely, exclusion from citizenship may be associated with lack of entitlement to vote or with marginalisation in undemocratic countries.

Trends such as globalisation, global migration, and the technological revolution along with uncertainty about the future all contribute to the view that schools must do more than prepare students for jobs, that citizenship education must be re-conceptualised and re-instituted as a centrepiece of public education.

The current multicultural situation in Morocco has a number of distinctive features. Since independence in 1956, global processes of the internationalisation of the economy, enhanced communication networks, and cultural currents have been changing the character and functions of the society, and a person's identity as a member of the nation has been uncoupled from their rights.

Since Morocco's independence until very recently, citizenship education has not been a central purpose of public education. This view is supported by the neglect of social studies education over the past three decades, which has begun to have the effect of leaving a large proportion of the student population without a sufficient knowledge base to make informed decisions regarding public affairs or civic responsibilities.

The national charter of education has recently raised concern about the appropriateness of curricula and the necessary development of resources. Today, 
it appears that interest is spreading into the wider education community, especially with the potential introduction of citizenship courses like 'asha? $n$ al maHalli' (local affairs). Public education, as a cornerstone of democracy and citizenship education, should be central to the provincial education programme.

The concept of citizenship should be broadly defined to encompass multiple dimensions applied locally, nationally, and globally and based on such values as respect, tolerance, acceptance, open-mindedness, non-violence, equality, commitment to social justice, and concern for the common good.

Responsibility for citizenship education rests with the school, the family and community, and with society at large through government support for public education. Citizenship education is relevant to students' interests and involves active engagement and critical thinking and advanced levels of literacy. Citizenship education should include community service work that would help draw school and community closer together.

\section{Historical background}

Since the $8^{\text {th }}$ century, an Islamic traditional system of education was prevalent in Morocco. Qur'anic and religious schools offered an Islamic traditional style of education. They taught mainly the Arabic language and the holy Qur'an for centuries; the University of Qarawiyyine at Fès, built in the $8^{\text {th }}$ century, helped students to pursue and deepen their knowledge of Arabic and Islamic thought (see Grandguillaume, 1983, p. 70).

Moroccan sultans encouraged education and Islamic studies. Sultan Moulay Hassan (1873-1894) incited scholars (ulamas) to debate modern issues, and his interest in higher education was basically aimed to modernise the society and to introduce reforms. Men of learning played a great role in the community (Burke, 1972), and Morocco's sultans used scholars' support to bestow legitimacy on their power (Al-Fassi, 1954, pp. 276-277) ${ }^{2}$. Educated people enjoyed a great deal of prestige in the Makhzen (government) and in Moroccan society at large (see Eikelman, 1985, p. 4). Religious knowledge remained highly viewed by the Islamic 'Umma' (nation) throughout the Islamic world; it was and still is indeed the most culturally valuable knowledge (Rosenthal, 1970), and is considered a valuable form of cultural capital (Bourdieu, 1973, p. 80).

The universities Qarawiyyine and Yusufia continued to receive students from intellectual, religious, and political circles from different parts of the country. In the 1920s, reformists introduced subjects like Classical Arabic literature, theology, Islamic law (shari' $a$ ), and history. Although the main objective was to teach and learn the religious sciences, the studies also helped the graduate to attain positions 
in the government as a judge (qadi), a secretary (katib), a teacher (fqih), an imam in the mosque. These skills were equally used to engage in political and social activities and establish social networks and economic advantages.

Morocco was colonised by two European powers in the $20^{\text {th }}$ century: France and Spain. The French colonial power justified its existence by claiming that it had a mission to civilise and develop the region. But politically the real reason was that the French wanted to dominate Morocco and subjugate its population. Economically the intention was to exploit the raw materials and use cheap labour to the advantage of the European market. The main objective of colonialism was to perpetuate the political and economic dependence of the indigenous people. Concerning education and science, the kind of colonial education reserved for the local populations (whose objective was to train people for low-level jobs) and the economic policy adopted meant that Moroccan natives would remain dependent and under-developed in these fields.

The French colonial presence in Morocco provoked two different processes: first, the spread of French language and culture, and the acculturation or alienation of the masses, and second this caused anti-colonial feelings among nationalists. The latter reaction took violent forms in the struggle for independence, and was based on religious motives which are still strong among the population. After independence, almost the opposite tendency resulted, as many young people and intellectuals seemed to insist on learning French language and culture for pragmatic goals (for the reasons of social promotion and openness to the West). Today, there is a rush to the French schools and classes especially in urban centres (see Ennaji, 2005, p. 105).

During the colonial period, the French colonisers made great efforts to dissociate Moroccan society from its indigenous languages and cultures. The French endeavoured to divide the country into ethnic groups to facilitate the colonisation process. This act was not arbitrarily implemented; rather, it was carefully planned because the colonisers were aware of the strong feelings of ethnic group membership in the region.

On 16 May 1930, the French issued the Berber Dahir, which formally put Berber-speaking zones under the customary law courts instead of the Islamic jurisprudence. Both Berberophones and Arabophones stood against this decision. Demonstrations spread all over the country, from Sale, to Fès, to Rabat, in order to express Moroccans' utter condemnation of this decree which sought to divide and rule Moroccans ${ }^{3}$. The Dahir was presented as an attack on Islam and a threat to Muslim values and principles. From that period onward, the French efforts in education, scarce as they were, were viewed with scepticism, and people started to understand French rule as a menace against Islam. Many nationalist meetings were held in mosques. The nationalist movement gained momentum in the mid-1930s, 
and the moment the French authorities arrested Kind Mohammed V and exiled him and his family to Corsica and then to Madagascar on 20 August 1953, the beginning of the end of the French occupation started (Eickelman, 1985, p. 102).

The French introduced modern education but only in favour of their own children and at best in favour of the children of the Moroccan elite and collaborators. Education continued to be elitist under the French rule, and standards were high. For lack of large numbers of university graduates, primary certificate holders were appointed in high positions. According to Waterbury (1970, p. 84), between 1912 and 1954, only 530 Moroccan students passed the end of high school certificate (French Baccalauréat). Mass education started after independence; only 25,000 students were registered in primary education in 1955, and 130,000 new students entered the primary cycle in 1856. Popular enthusiasm for modern education grew as the link between socioeconomic mobility and educational achievement was strong.

Despite the decline of Islamic higher education during the French occupation, cognitive studies remained the main style of learning, influencing the nationalist movement and the political action in the country. The pursuit of religious knowledge among Arabic and Berber speaking people was commendable although it did not necessarily lead to social promotion or economic advantages.

At the beginning of the $20^{\text {th }}$ century, religious scholars were basically the only Moroccans with full literacy in Classical Arabic. Until recently, literacy has been possessed only by a minority in Morocco. Educated people had such a great social respect that, without their cooperation, the French colonisers would not have succeeded to pacify Morocco and expand their administrative power all over the country. However, when the French authorities used violence and direct intervention, many intellectuals and scholars joined the resistance and the nationalist movement for independence led by Allal El-Fassi and Mohamed Hassan Ouazzani and many others.

According to Laroui (1967, pp. 19-28), Arab intellectuals can be divided into three categories. First, there are the religious scholars and clerics who seek to improve the society while maintaining the dominance of Islamic thought and values. Second, there are the liberal politicians, who aim to modernise society by adopting Western norms and ideas and political reforms. The third category is that of Western-educated technocrats and apolitical intellectuals, who seek the betterment of society through the adoption of socialist or Western know-how and rational thinking. I agree with Laroui when he notes that the clerics are usually less interested in establishing dialogue with Westerners. However, Laroui's division is vague and not $100 \%$ correct since there is a large overlap between the three categories; furthermore, the elite's attitudes change over time, and the first category, which is the most complex, is vaguely defined. 
Religious knowledge in Morocco is characterised by orality, especially in the Berberophone areas; religious scholars venerate the words in the Qur'an which they memorised by heart with the purpose of spreading and transmitting the Holy Book and the traditions of Prophet Mohammed, without alteration or falsification, from generation to generation. Until very recently, literacy in Morocco entailed religious schooling, with the first years of study emphasising memorisation and recitation of the Qur'an; the subsequent years consisted of learning reading and writing. The literacy estimates of the early $20^{\text {th }}$ century are indicative of the scale of traditional education in Morocco. In the 1930s, the rural areas witnessed a literacy rate of $4 \%$ of the adult male population and $20 \%$ of the adult male urban population (Geertz, 1979, pp. 470-487). As to the overall rate of literacy among women, it was less than 1\% (cf. Eickelman, 1985, p. 60; Ennaji, 2005, p. 219).

Qur'anic teachers (fqihs) played an important role in the memorisation of the Qur'an; up until the beginning of independence fqihs taught Arabic and Islamic thought in mosques, medersas, and elementary schools. The fact that they were not generally rich did not preclude their respect and high esteem of society as carriers of the Qur'an (Waterbury, 1970, p. 32).

For most students, this was the only form of education they could achieve. Only the fortunate few could access Qarawiyyine or Yusufia University. Both universities were also used by the community as spaces for worship and other pious meetings in such a way that the university was both a mosque and a learning centre. Lessons, which were held five times weekly, were organised around 'the daily cycle of prayers' in the form of circles of teachers and students, and were open to the public, which indicated popular support to these lessons. The teaching and learning activities were related to the needs and expectations of the community. For accommodation, hostels were reserved to students of these institutions (Geertz, 1979, p. 469).

From the 1930s onward, and well after independence, the shift went in favour of modern Western-type of education, and religious scholars were no longer reproduced in large numbers, although they continued to enjoy considerable respect in the community. Higher Islamic education lost its vitality because the French colonisers imposed reforms to the two major universities and appointed salaried teachers, whom they controlled. Gradually, religious education was left to students from poor socioeconomic backgrounds or of rural origins. For comparison, according to Marty (1924, p. 337) and Berque (1974, p. 173), in 1924 there were 300 students from the city of Fès and 419 from rural areas at Qarawiyyine University. In 1938, only 100 students from Fès and 800 from poor or rural backgrounds were registered. As to the Yusufia University in Marrakesh, estimates mention that in the early 1930s there were about 250 students from the city of Marrakesh, and 150 from neighbouring villages; these numbers dropped in 1935 
to a few dozens of students. Islamic education after independence became less sought for because it lacked analysis and it did no longer meet the needs of the job market. The post-independence governments had to focus their efforts on modernising education and society. Moroccans regarded their children's futures as dependent on their training in French and their acquisition of certification that only French education could offer.

This shift in interest shows the close link between education and society in the Moroccan context and the way in which value is placed on various forms of learning, traditional or modern. For this reason, religious scholars and traditional 'ulamas' sent their own children to Francophone schools rather than to religious schools and universities. Even nationalist leaders from prominent urban families like Allal El-Fassi, Mohamed Hassan El-Ouazzani, and King Mohammed V, all sent their children to French-run schools (Waterbury, 1970, p. 44).

Until the 1960s, students attended religious classes in mosques and memorised the Qur'an by heart, but today very few educated Moroccans could recite but a few verses from the Qur'an. Religious education is referred to officially by the terms 'lettres originales', which is reminiscent of the strong influence of French-style education, as the word 'original' does not seem compatible with 'modern' education. However, the fact that Islam is the state religion coupled with the affinity between popular thinking and religious education allowed the latter to keep its important place in society until today. As a consequence, Islamic higher education never actually disappeared. Being conscious of the important role of Islamic education, and of the necessity to control it, the government decided to preserve religious education and to open Islamic schools and institutes, the most important of which is Dar Al Hadith Al-Hassania in Rabat.

Today, Yusufia University is called the 'Faculty of Arabic Language', and its staff is totally Moroccan. Qarawiyyine University in Fès continues to be an important centre of Islamic learning with the main language of instruction being Arabic, although French and English are also taught as foreign languages. One of the consequences of these Islamic schools was the transformation of religiosity in the late $20^{\text {th }}$ century, with the expansion of Islamic associations like $\mathrm{Al}-\mathrm{Adl}$ wa $\mathrm{Al}$ Ihsan (extreme right NGO that challenges the establishment) and the Party of Justice and Development, which is a legal Islamist party, and who call themselves as Islamists (Islamiyyun) in sign of their self-description as the true carriers of Islamic values. The growth of these Islamist organisations is also the result of the success of the Iranian revolution, the fall of the Berlin wall, and the economic difficulties of post-independence, resulting in the strong social gap between the poor and the rich (see Eickelman, 1985, p. 175; Ennaji, 2005, p. 29). For the Islamists, independence did not bring development and progress, and Islam can lead to a profound transformation of society and to real progress and social justice. 
After the proclamation of independence, the French were successful in influencing the Moroccan system of education, hence the reinforcement of French language and culture in the curricula. The country's leaders recognised the need to place education at the centre of Morocco's socioeconomic and political future (see Damis, 1970).

Classical Arabic was declared the official language and French the second language. Since then, French has been used alongside Classical Arabic. The former has been adopted for purposes of modernisation and development, and the latter for preserving the country's cultural identity and authenticity. In this respect, Al-jabri (1973, p. 45) notes that the Moroccan elite is in full favour of keeping the essence of the educational system of the French colonisation and developing it on the basis of the French model.

Post-independence officials endeavoured to spread French in fields like trade, administration, education, and the media. In the name of achieving modernity and preserving cultural identity, the ruling elite opted for Standard Arabic-French bilingualism in most active sectors (cf. Grandguillaume, 1983).

Free education is provided to all children in public schools; the technical track offers subjects like engineering, economics, and agricultural sciences. Vocational training courses are also offered. English is introduced into the state curriculum in Grade 10 (first year of secondary school). English, however, is becoming popular in the private schools in Morocco (Clark, 2006).

Two different educational systems in Morocco have always co-existed. As mentioned earlier, the first one is the Islamic model of instruction at Qur'anic schools, which concentrates on Islamic studies and Arabic literature. The second is the modern model, adapted from the French type, to serve the needs of Modern Morocco. Although only a small percentage of students follow the original track, the government stresses its importance as a means of maintaining a sense of national and regional identity (Wagner \& Lotfi, 1980).

\section{Sociolinguistic context}

Morocco is characterised by multilingualism in the sense that many languages and varieties are used, including Classical Arabic, Standard Arabic, Moroccan Arabic, Berber, French, Spanish, and recently English. This multilingual dimension has a direct impact on the sociocultural life and education and brings about sociolinguistic problems that must not be overlooked in language planning and in education.

The most salient sociolinguistic feature of Morocco is the emergence of three forms of Arabic: Classical, Standard, and Moroccan Arabic (cf. Ennaji, 1991). 
Classical Arabic is the language of Islam, which is the vehicle of a great literary tradition and enjoys immense prestige among the population. Classical Arabic is culturally conceived as a sacred language because it is the language in which the Muslim holy book, the Qur'an, was revealed, and because it is a written code unlike the Arabic dialects.

Like Classical Arabic, Standard Arabic is a written Arabic variety which has no native speakers. Classical and Standard Arabic are both learnt at school only, as they are not spoken languages. Standard Arabic, which is structurally less rigid than Classical Arabic, is both codified and standardised; the policy of Arabisation has led to its modernisation and to its use as a vehicle of modern culture. It is widely made use of in education, administration, and the media. The expansion of free education has led to the spread of Standard Arabic and to favourable attitudes toward it (see Ennaji, 2005, pp. 53-58).

Moroccan Arabic is the mother tongue of at least $60 \%$ of the population, which unlike Classical and Standard Arabic, is unwritten but spoken. It is generally acquired by Arabophones as a native language, and learnt as a second language by Berberophones. Moroccan Arabic can be divided into several regional varieties, which are often mutually intelligible unless they are geographically distant from each other. However, Moroccan Arabic is usually stigmatised and treated as a corrupt form of Arabic (cf. Ennaji, 1991).

Berber is the mother tongue of approximately half the population, but it is looked upon by many Arabophones as debased essentially because it is not fully standardised as yet (although the process has started), has no religious connotations, and no great written literary tradition. These issues are dealt with in greater detail in the section on Berber education below.

Moroccan Arabic is spoken as a lingua franca by many Berberophones. Through it, the latter sometimes express their beliefs and feelings. Moroccan Arabic is used by both Arabophones and Berberophones as a means of expression of affective and cognitive experiences.

French is widely used as a second language. Despite its being a colonial language, it is still prestigious. Its chief domains of use are education, administration, government, media, and the private sector. It is employed to achieve efficiency, wider communication, and socioeconomic development.

Spanish is made use of to a lesser extent in the north and south of Morocco. It is optionally taught as a foreign language. By contrast, English is widely taught in high schools and universities. It is perhaps the most popular foreign language in the country because it has no colonial overtones (cf. Sadiqi, 1991; Errihani, 2008).

Morocco is also characterised by Arabic-French code switching, which occurs when there is a juxtaposition of strings of words formed according to the patterns and grammatical systems of both languages. Educated bilinguals code switch 
regularly between Moroccan Arabic and French (for example: 'aji shuf l'ordinateur est bloqué'; meaning: 'come see the computer is stuck'). This code switching takes places mainly in informal situations during daily verbal interactions among schooled or highly educated people. In formal settings, however, Moroccan bilinguals use only one of these codes since formal contexts or specialised topics call for the use of one language exclusively.

Studies of Moroccan Arabic-French code switching have been developing since the 1970s. They have dealt with bilinguals' choice to switch between Moroccan Arabic and French from sociolinguistic, psycholinguistic, and grammatical perspectives (Ennaji, 2005, pp. 139-156).

Sociocultural factors like geography, education, age, gender, and class determine the nature and extent of code switching. Code switching tends to be an urban phenomenon (see Caubet, 1998; Sadiqi, 2003, pp. 257-271) in the sense that most code switchers are usually educated city dwellers; however, people who code switch differ in their competence in the two languages concerned. There are different types of code switchers depending on the languages they switch, their linguistic ability and the topics dealt with. On the other hand, code switching entails informality, intimacy, or solidarity between code switchers. Myers-Scotton (1993) calls this phenomenon 'solidarity syndrome'. Code switching shows precisely the 'innovative accommodation' in engaging with both languages, both traditions, both mind-sets at the same time (Zughoul, 1978).

There are administrative factors which regulate the degree of code switching. Given that the Moroccan administration is bilingual, there is a tendency to shift from French to Standard Arabic in formal situations. In less formal contexts (administration meetings, social address, etc.) there is more shift from Moroccan Arabic to French or Standard Arabic. But most of the written work is done in Standard Arabic or French. In most of the above situations, code switching between Moroccan Arabic, Standard Arabic and French takes place.

Moroccan Arabic-French code switching is stigmatised (cf. Ennaji, 1988; Lahlou, 1991; Caubet, 1998). Despite being negatively viewed by most Moroccans, code switching is part and parcel of the multilinguistic panorama of the country, and the Maghreb in general.

Educated people are not all favourable to code switching. The Arabic-educated intellectuals (Arabisants) loathe this form of speech which they consider corrupt and a sign of loss of identity. However, the French-educated people tend to be in favour of code switching, which they regard as a symbol of high social status (see El-biad, 1991; Lahlou, 1991; Moatassim, 1992). In education, code switching is quite common, especially in science classes; many teachers mix Moroccan Arabic and French to explain scientific and technical phenomena. 
For many intellectuals, code switching is one of the residues of cultural colonisation and a sign of lack of pride in Arabic language and culture. Moatassim (1974) qualifies code switching as a poor form of expression, and Guessous (1976) states that it is a 'bastard language' in the Moroccan multilingual and multicultural context. Code switching is in fact the most salient feature of the Arabisation policy applied since independence with the overall goal of generalising the use of Standard Arabic to all domains as a language of wider communication instead of French, which is considered by conservatives to be a threat to the linguistic and cultural identity of the country.

\section{Arabisation and bilingual education}

Given the connection between Standard Arabic, Islam, and nationalism, Arabisation may be considered a sign of the revival of the Arabic language and culture. Arabisation is strongly supported by religious groups and fundamentalists. Abdelaziz Benabdallah, ex-director of the permanent office of Arabisation, highlighted the invaluable role of Classical and Standard Arabic in an interview which appeared in the Moroccan daily Le Matin of Sunday 2 November 1997.

Furthermore, most scholars support bilingualism or mastery of foreign languages in addition to Arabic. The eminent Moroccan lexicographer, Lakhdar Ghazal, (ex-director of the Institute of Arabisation in Rabat, Morocco) argues that if Arabisation is a duty, Arabic-French bilingualism is a necessity as far as it serves the enrichment of Standard Arabic.

Arabisation is not only a language problem, but also a political and ideological matter. Right-wing political parties like the Istiqlal party and the Justice and Development party advocate total Arabisation at the expense of mother tongues (cf. Al-jabri, 1995). Progressive and modern scholars advocate bilingualism and the revival of mother tongues (cf. Boukous, 1995; Ennaji, 1997 and the references cited there). The Arabisation policy has in a way been turned against the public authorities, as it is often used by the opposition parties and by Islamists as a tool in their fight for power.

Despite four decades of Arabisation, French is still widely used in education, administration, and the private sector. The efforts of Arabising the educational system have not fully succeeded for three main reasons: (i) the place of French is still very strong in key socioeconomic factors; (ii) the ruling elite holds negative attitudes toward Arabisation and the way it has been politicised and implemented; and (iii) the official language policy has been inconsistent, and as a result there seems to be no plan to Arabise higher education. 
The unfair dichotomy between written languages, that is, Classical Arabic, Standard Arabic, English, and French, on the one hand, and spoken languages like Moroccan Arabic and Berber, on the other hand, is sharpened by the policy of Arabisation whose aim is to introduce Standard Arabic in all fields of activity, as it is the symbol of cultural independence ${ }^{4}$.

Arabisation has had negative consequences on the Berber language because it has led to its marginalisation and to the assimilation of the Berber culture and people. However, in 2001 the government decided to revitalise Berber and introduce it in the educational system.

The fact that the post-independence government opted for Arabic-French bilingualism in education was certainly a pragmatic choice. However, this type of bilingualism is more imposed by historical, political and economic factors than chosen. The major reforms after independence have been the omission of French from the first two years of public primary schools and the increase of the teaching load of Arabic and the strengthening of the position of French in university, especially in science faculties ${ }^{5}$.

This kind of bilingualism and biculturalism is the source of difficulty for learners in schools because of the different and at times conflicting roles of Arabic and French. This difficulty is translated in reality by the high rate of failure and dropouts in primary, secondary, and higher education, hence the adoption of the Arabisation policy whose aim is to reduce the number of dropouts and the failure rate at school (Grandguillaume, 1983). In 1973, the government decided to Arabise mathematics and the sciences in the primary and secondary education, and philosophy and the social sciences at all levels of education; French thus became de facto a second language, and Arabic the language of instruction of all disciplines in primary and secondary education. However, up until now, the sciences are taught in French in higher education, whereas the faculties of science, medicine, engineering, and private institutes use French as the language of instruction.

The political leaders' stand on Arabisation and bilingualism has evolved since independence. While the enthusiasm for Arabisation was very strong immediately after independence, nowadays, it is waning as a result of unemployment among Arabised university graduates.

The ambiguity and hesitation that have characterised the educational system and the language policies adopted in a way reflect the painful acculturation and alienation that a whole generation of politicians, officials, and people have suffered in the post-colonial era.

The expansion of bilingual and bicultural education to masses of pupils and students from different sociological backgrounds after independence has led to their alienation and consolidated acculturation. 
Bilingual education is a political option which has a serious impact on education and citizenship, and fosters communication with the West and the rest of the world (see Fitouri, 1983). However, after decades of the implementation of the Arabisation policy, the degree of mastery of French has regressed; yet, the prestige of French prevails and attitudes toward it remain for the most part favourable ${ }^{6}$.

The multicultural context in Morocco hides a class struggle, group competition, a clash of interests of the different sociocultural categories, as well as ideological tensions, which pose problems for citizenship. These tensions and conflicts reflect also the fight for power at various levels (cf. Grandguillaume, 1983; Ennaji, 1991; Boukous, 1995 among others). The multicultural context is instrumentalised by the progressive forces to consolidate democracy, citizenship, and minority rights, while the traditionalists (particularly the Islamists) use it as a political tool to give vent to their ideology and their political agenda with the aim of re-Islamising the country and ruling in the name of Islamic religion and culture.

Thus, the debate about Arabisation and bilingual education implies a larger debate on citizenship, government policy, ideology, politics, religion, culture, and identity. Arabisation policy is a hidden fight for social promotion used by opposition political parties and the lower social classes in the hope that Arabisation will re-establish collective rights, social justice, and equal opportunities for all.

As mentioned above, Berber, considered by many as a 'minority' language, has been marginalised by Arabisation and by French-Arabic bilingual education. However, since 2001 the authorities have called for the revival of Berber language and culture as a sign of reinforcing citizenship. In the following section, I discuss the impact of Berber on education.

\section{Berber education}

Historically, although at least half of the population speaks Berber, preference has always been given to Latin and later on to Arabic as the official language of the nation. Berber has never been recognised as the official language, nor introduced in the educational system, until 2003.

After independence, Berber was excluded from schools in the name of statebuilding and in search of a unified national identity. This forced a whole generation of children to enter school in a language they had never spoken before, contributing to a higher dropout rate among Berber children. Trouble for Berberonly speakers did not stop in the educational system. Many continued to face other difficulties communicating in hospitals and the court system, where Arabic and French dominated. 
The frustration led to two major Berber revolts - one in 1973 and a second in 1994 - both of which the Moroccan government suppressed. But by mid-1990s the Berber movement was strong enough to catch the attention of King Hassan II, who on 20 August 1994 publicly vowed to integrate the indigenous tongue into the education system. However, there was little progress until King Mohammed VI, whose mother is Berber, took over. In 2001, he announced a programme to teach all schoolchildren Berber and declared the creation of a research institute, The Royal Institute of Berber Culture in Rabat, to develop a curriculum and promote the study of the Berber language. This initiative gave the teachers the chance to spend three hours a week teaching Berber to their students, in addition to Arabic and French.

The official recognition of Berber as part of the national heritage and cultural authenticity, and its introduction in Moroccan primary schools are good examples of the revival of this language. This revival is due mainly to the fact that both Arabic and Berber cultures play a strong symbolic role in strengthening the national identity, multiculturalism, and citizenship.

As a result of this move, the authorities have tentatively introduced Berber in a number of primary schools and plan to generalise its teaching and its use in the media. On television, the new move is the broadcasting of news bulletins, films, and advertising in Berber language. Attitudes to Berber have changed favourably since the royal speech of Ajdir on 17 October 2001 when the king announced the policy for the promotion of Berber language and culture. Attitudes toward Berber have in general become favourable (see Ennaji, 2003), and Berber academics and associations are working on how to standardise and unify their language. The number of Berber cultural associations has multiplied (more than 60 exist in Morocco). Their objective is to revitalise Berber language and culture, and sensitise people and government to the cultural value of Berber as part of and parcel of the national legacy and Moroccan citizenship.

In the field of education, one may state that the teaching of Berber is spreading steadily; Berber is taught in over 900 public schools and in many private schools, including the French Institute in Agadir and NGOs working for the dissemination and protection of this language both in Morocco and Europe, where there is a large Moroccan immigrant community (see Quadéry, 1998; Kratochwil, 1999). In 2007, nearly 300,000 students - native Arabic speakers as well as Berber speakers were enrolled in Berber courses, according to the Ministry of Education (cf. Errihani, 2008).

Since the creation of the Royal Institute of the Berber Culture, the existing multilingual and multicultural dimension of Morocco has been recognised, and a new language planning, codification, and standardisation policy has been launched so as to integrate this language not only into the educational system, but into the different sectors as well. 
In 2000, the National Charter for Education and Training was adopted with the aim to restructure the Moroccan educational system and language policy in order to upgrade the standards. The Charter outlined the role of Berber in society and the need to introduce it in education, as well as the need to have a good command of Arabic and foreign languages.

However, it would be interesting to find out whether the type of language policy set out by the Charter is compatible with the country's sociolinguistic and multicultural reality. Moreover, it would be of paramount importance to investigate the extent to which multilingualism and multiculturalism can be a source of conflict in language teaching and learning.

The official support for Berber has helped fuel a larger revival of Berber culture and life in the kingdom, where the country's native people have long been shunned, and sometimes imprisoned, for public expressions of their heritage. Nowadays, summer arts festivals are commonplace, Berber newspapers are thriving, and a long-blocked translation of the Qur'an into Tamazight finally made it into print.

Of course, the transformations have been far from uniform, and there are signs that the slow pace of change is beginning to exacerbate the tension between the government and Berber activists. Yet the story of the Berber project and the challenges it has faced from politicians, parents, and Berber natives is in many ways symbolic of the broader struggle Morocco faces as it tries to balance the competing interests of a multicultural country of over 30 million (Schwartz, 2008).

Though the government initiative calls for adding a new level of Berber each year, many schools have offered only the first level for the past three years. Many still have no Berber teachers, and the Ministry of Education will not allocate money to recruit new ones - a position that many Berber people see as a sign that the Arab-dominated government has not fully accepted the initiative. Textbooks are not always sent to rural areas, where Berber speakers are often the majority. Other promises, such as plans to launch an all-Berber television station and develop university-level programmes on Berber culture, have not materialised either. As a result, many Berber activists are beginning to criticise and distance themselves from the officials' efforts. In 2005, for instance, seven of the 30 board members of The Royal Institute of Amazigh Culture (IRCAM) resigned because of the constant pushback from the state.

Despite all the obstacles, Berber is no more a forgotten national dialect, but a subject in its own right in Moroccan primary schools. Different positions arise concerning its introduction in education. The attitudes range from those of Berbers advocating the promotion of Berber to some Arabophones who are opposed to the idea of revitalising it. Many refute Berber as a mandatory subject in primary schools, claiming that it is useless in the job market. 
Proponents of the teaching of Berber argue that it will motivate Berberspeaking students to continue their education and facilitate their socioeconomic integration and strengthen their sense of citizenship in a multicultural society (see Jackson, 2004, p. 21; Ennaji, 2005, p. 217).

\section{Conclusion}

Fifty-three years after independence, the multicultural situation and the educational system in Morocco have witnessed many changes. Although French remains important especially in higher education and in the private sector, Arabic has been consolidated through the Arabisation process. English has emerged as the most popular foreign language with no colonial connotations, and Berber has finally been introduced in elementary education. Moreover, the presence of Islam, which constitutes a fundamental cultural component side by side with Western culture, must also be taken into account, as a symbol of unity and a token of Morocco's cultural diversity.

One of the major hurdles faced by the Moroccan system of education since independence has to do with the ambivalence and the indecisiveness of decisionmakers with regard to the management of multiculturalism and its impact on citizenship. The hesitation is flagrant specifically with regard to the officials' attitude toward Berber and its introduction in the educational system. Although Berber is taught in elementary schools, it is not yet recognised in the constitution as an official language, nor as a national language. The ambivalence equally concerns the Arabisation policy, which has been implemented in primary and secondary education, but not in tertiary education for ideological and political reasons. This reveals the complexity of the post-colonial Moroccan society.

Thus, the national community's ideas have not always been inclusive of all the cultural components of Moroccan society, and despite new efforts, the state does not strongly sustain modern definitions of citizenship. Factors like social movements, politics, and education, however, play a key role in constructing a sense of citizenship and identity.

A judicious reform of education is badly needed in order to achieve sustainable development, tolerance, social cohesion, and the preservation of Moroccan cultural identity. Integrating multiculturalism and citizenship issues may develop critical thinking, empower students to take action for problem-solving, and develop their awareness of citizen issues and global issues (cf. Ennaji, 2004).

Citizenship ought to be consistent with democratic values, namely respect for human rights, multiculturalism, and the rule of law. Educational authorities and decision-makers must adopt a multicultural approach as an efficient tool 
for addressing pluralism and cultural diversity and for enhancing multicultural education and citizenship, which include students' right to be prepared appropriately for life as citizens playing a full part in democracy.

All in all, the nature of the political institutions, the political processes and governmental policies to a great extent structure the kinds of social and political relationships that ensue in a multicultural society. In such a society, individuals naturally prefer and promote the interests of their own group. By negligence and mismanagement, this attitude could degenerate into tension and conflict. Democratic culture and good governance have proven to be capable of changing the outcome of the social, political, and economic processes from being confrontational to national accommodation.

\section{Notes}

1. France in the modern era pioneered the definition of an active citizenship that was inclusive of all who accepted the principles of the Revolution and French culture. The availability of French citizenship to the children of immigrants on condition of their education in, and identification with, French culture expresses the idea of the French nation as a 'daily plebiscite'. Yet the very presence of immigrants who utilise the right to be different against the universalism of the rights of the citizen has caused French people to reassess the nexus between citizenship and ethnic nationality.

2. To encourage education, annual celebrations for religious students were held at Qarawiyyine University in Fès and Yusufia University in Marrakesh. Students chose a 'mock' sultan among them and other students constituted the crowd and the whole procession walked in a parade in the main streets of the city (this was called in Arabic 'Sultan Tolba', i.e., the sultan of students). The Sultan sent gifts to the best students. However, in 1925, this tradition was discontinued by the French rulers who feared that this event had political implications.

3. People read the latif in the mosques, 'a collective invocation to God in times of disaster'.

4. Today, the Tifinagh alphabet is used to write Berber, and efforts are made to generalise its use to the whole Maghreb region. In Morocco, short stories and novels are nowadays written in Berber.

5. In addition, the government applied four principles in education: the generalisation of schooling to all the population which led to an extension of education; the unification of education (the same programmes have been adopted all through the country); free education to all (no tuition fees are paid); and Moroccanisation and Arabisation of education, which implied hiring Moroccan teachers to replace foreign ones, and progressively consolidating Modern Standard Arabic as the language of education, instead of French.

6. This is due to the fact that French is still the language of scientific, technical, and business studies, whereas Arabic and Berber remain the language(s) of cultural authenticity and ethnic identity expressing intimate, emotional, and spiritual values and beliefs (Gill, 1999).

\section{Acknowledgements}

I would like to thank very warmly Ronald Sultana (University of Malta), André Mazawi (University of British Columbia, Canada) and Fatima Sadiqi (University of Fès, Morocco) for reading and commenting on earlier versions of this paper, which led to its improvement. 
Moha Ennaji is professor of Linguistics, Culture and Gender Studies, director of the international journal 'Languages and Linguistics', president of the South-North Center for Intercultural Dialogue and Migration, and director of the International Festival of BerberCulture.His e-mail address is: mennaji2002@yahoo.fr

\section{References}

Al-Fassi, A. (1954) The Independence Movement in Arab North Africa (translated by Hazen Zaki Nuseibeh). Washington, DC: American Council of Learned Sciences.

Al-jabri, M. A. (1973) On the Question of Education in Morocco (in Arabic). Casablanca: Dar Annashr Almaghribiya.

Al-jabri, M. A. (1995) The Question of Identity (in Arabic). Beirut: Publications of the Center for Arab Unity Studies.

Aronin, L., \& Singleton, D. (2008) Multilingualism as a new linguistic dispensation, International Journal of Multilingualism, Vol. 5(1), pp. 1-16.

Berque, J. (1974) Lieux et moments du réformisme Islamique. In Maghreb: Histoire et Sociétés. Paris: Editions J. Duculot.

Boukous, A. (1995) Société, Langues et Cultures au Maroc. Rabat: Publications de la Faculté des Lettres.

Bourdieu, P. (1973) Cultural reproduction and social reproduction. In R. Brown (ed.) Knowledge, Education and Cultural Change. London: Tavistock Publications.

Bourdieu, P. (1982) Ce que Parler Veut Dire. Paris: Fayard.

Burke, E., III (1972) The Moroccan Ulama, 1860-1912: an introduction. In N. R. Keddie (ed.) Scholars, Saints, and Sufis. Berkeley \& Los Angeles: University of California Press.

Caubet, D. (1998) Alternance de codes au Maghreb: pourquoi le Français est-il Arabisé?, Plurilinguismes, Vol. 14, pp. 121-142.

Clark, N. (2006) Education in Morocco, WENR, Vol. 19(2/3), pp. 5-16.

Damis, J. J. (1970) The Free-School Movement in Morocco (translated into Arabic by Said Moatassim in 1991). Casablanca: Tansift Publishers.

Eickelman, D. (1985) Knowledge and Power in Morocco. Princeton: Princeton University Press.

El-biad, M. (1991) The role of some population sectors in the progress of Arabization in Morocco, International Journal of the Sociology of Language, Vol. 87, pp. 27-44.

Ennaji, M. (1988) Language planning in Morocco and changes in Arabic, International Journal of the Sociology of Language, Vol. 74, pp. 9-39.

Ennaji, M. (1991) Aspects of multilingualism in the Maghreb, International Journal of the Sociology of Language, Vol. 87, pp. 7-25.

Ennaji, M. (1997) The sociology of Berber: change and continuity, International Journal of the Sociology of Language, Vol. 123, pp. 23-40.

Ennaji, M. (2003) Attitudes to Berber and Tifinagh. In M. Peyron (ed.) Proceedings of the Conference on Amazigh Language and Culture. Ifrane: Al-Akhawayn University Press. Ennaji, M. (2004) Teaching citizenship in the Moroccan context. In A. Zaki (ed.) Proceedings of the $21^{\text {st }}$ MATE Conference. Rabat: MATE Publications. 
Ennaji, M. (2005) Multilingualism, Cultural Identity, and Education in Morocco. New York: Springer.

Errihani, M. (2008) Language Policy in Morocco: Implications of Recognizing and Teaching Berber. Saarbrücken: Vdm Verlag Dr. Müller.

Fairclough, N. (1989) Language and Power. London: Longman.

Fishman, J. (1998) The new linguistic order, Foreign Policy, No. 113 (Winter), pp. 26-40.

Fitouri, C. (1983) Biculturalisme, Bilinguisme et Education. Paris \& Neuchatel: Delachaux \& Niestlé.

Geertz, C. (1979) Suq: the bazaar economy in Sefrou. In C. Geertz, H. Geertz \& L. O. Rosen (eds.) Meaning and Order in Moroccan Society. New York \& Cambridge: Cambridge University Press.

Gill, H. (1999) Language choice, language policy and the tradition-modernity debate in culturally mixed postcolonial communities: France and the 'Francophone' Maghreb as a case study. In Y. Suleiman (ed.) Language and Society in the Middle East and North Africa. London: Curzon.

Grandguillaume, G. (1983) Arabisation et Politique Linguistique au Maghreb. Paris: Maisonneuve et Larose.

Guessous, M. (1976) Bilingualism and biculturalism (in Arabic), Al-Mouharrir, Vol. 2(5), pp. 11-12.

Jackson, R. (2004) Rethinking Religious Education and Plurality: Issues in Diversity and Pedagogy. London: Routledge Falmer.

Kratochwil, G. (1999) Les associations culturelles Amazighes au Maroc: bilans et perspectives, Prologues: Revue Maghrébine du Livre, No. 17, pp. 31-40.

Kymlicka, W. (1995) Multicultural Citizenship: A Liberal Theory of Minority Rights. Oxford: Oxford University Press.

Lahlou, M. (1991) A Morpho-Syntactic Study of Code Switching between Moroccan Arabic and French. Ph.D. thesis, University of Texas at Austin, USA.

Laroui, A. (1967) L'Idéologie Arabe Contemporaine. Paris: François Maspéro.

Marty, P. (1924) L'Université de Qaraouiyne. In Renseignements Coloniaux, Supplément de l'Afrique Française. Paris: Presses Universitaires de France.

Maurais, J. (2003) Towards a new linguistic world order. In J. Maurais \& M. Morris (eds.) Languages in a Globalizing World. Cambridge: Cambridge University Press.

Moatassim, A. (1974) Le bilinguisme sauvage, Tiers-Monde, Vol. XV, pp. 619-670.

Moatassim, A. (1992) Arabisation et Langue Française au Maghreb. Paris: Presses Universitaires de France.

Myers-Scotton, C. (1993) Social Motivations for Code Switching: Evidence from Africa. Oxford: Oxford University Press.

Quadéry, M. (1998) Les berbères entre le mythe colonial et la négation nationale: le cas du Maroc, Revue d'Histoire Moderne et Contemporaine, Vol. 45(2), pp. 39-47.

Rosenthal, F. (1970) Knowledge Triumphant: The Concept of Knowledge in Mediaeval Islam. Leiden: E. J. Brill.

Sadiqi, F. (1991) The spread of English in Morocco, International Journal of the Sociology of Language, Vol. 87, pp. 99-114.

Sadiqi, F. (2003) Women, Gender, and Language in Morocco. Leiden: Brill. 
Schwartz, E. (2008) Morocco's Berbers reclaim their language and their indigenous culture. U.S. News \& World Report, 13 March. Available online at: http://search. usnews.com/index_library/search?keywords $=$ Schwartz+morocco+ berber $\& x=33 \& y=9$

Sklair, L. (1999) Competing conceptions of globalization, Journal of World-Systems Research, Vol. 5(2), pp. 143-162.

Stevenson, N. (2002) Cosmopolitanism, multiculturalism and citizenship, Sociological Research Online, Vol. 7(1). Available online at: http://www.socreonline.org.uk/7/1/ stevenson.html

Wagner, D. A., \& Lotfi, L. (1980) Traditional Islamic education in Morocco: sociohistorical and psychological perspectives, Comparative Education Review, Vol. 24(2), Part 1 (June 1980), pp. 238-251.

Waterbury, J. (1970) The Commander of the Faithful: The Moroccan Political Elite. New York: Columbia University Press.

Zughoul, M. R. (1978) Lexical interference of English in Eastern Province Saudi Arabia, Anthropological Linguistics, Vol. 20(5), pp. 214-225. 